\title{
Восприятие цитокининового сигнала у картофеля
}

\author{
С.Н. Ломин*, Ю.А. Мякушина, О.О. Колачевская, И.А. Гетман, Д.В. Архипов, \\ Е.М. Савельева, Г.А. Романов \\ Институт физиологии и растений имени К.А. Тимирязева РАН, Москва, Россия \\ *e-mail:losn@inbox.ru
}

Картофель - самая экономически важная незлаковая пищевая культура. Образование клубней в картофеле регулируется фитогормонами, цитокининами в частности. В настоящей работе изучалось восприятие сигнала цитокинина в картофеле. Секвенированный картофельный геном дублированного моноплоида Phureja использовался для биоинформационного анализа и как инструмент для идентификации предполагаемых цитокининовых рецепторов из автотетраплоидного картофеля сорта Désirée. Bce основные элементы многоступенчатого каскада фосфорилирования, необходимые для трансдукции сигнала цитокинина, были идентифицированы в геноме Phureja, включая три гена, ортологичных трем генам рецепторов цитокинина (АНК 2-4) арабидопсиса. В отличие от Phureja, автотетраплоидный картофель содержит по меньшей мере две аллельные изоформы каждого типа рецептора. Предполагаемые рецепторные гены растений Désirée были клонированы, секвенированы и экспрессированы, и определены основные характеристики кодируемых белков, в частности их структура, консенсусные мотивы, лиганд-связывающие свойства, способность передавать сигнал цитокинина. Во всех изученных аспектах предсказанные признаки гистидин-киназ отвечали требованиям к подлинным цитокининовым рецепторам. Экспрессия картофельных цитокининовых рецепторов была органспецифичной и чувствительна к условиям роста, особенно к содержанию сахарозы. Наши результаты обеспечивают прочную основу для дальнейшего углубленного изучения системы сигнализации цитокининов и биотехнологического улучшения картофеля.

Благодарности: Работа выполнена при финансовой поддержке гранта РНФ № 17-74-20181. 